\title{
The impact of IL28B genotype on the gene expression profile of patients with chronic hepatitis $C$ treated with pegylated interferon alpha and ribavirin
}

Zobair M Younossi ${ }^{1,2,3^{*}}$, Aybike Birerdinc ${ }^{1,2}$, Mike Estep ${ }^{1,3}$, Maria Stepanova ${ }^{1,2,3}$, Arian Afendy ${ }^{1,3}$ and Ancha Baranova ${ }^{1,2}$

\begin{abstract}
Background: Recent studies of $\mathrm{CH}-\mathrm{C}$ patients have demonstrated a strong association between IL28B CC genotype and sustained virologic response (SVR) after PEG-IFN/RBV treatment. We aimed to assess whether IL28B alleles rs12979860 genotype influences gene expression in response to PEG-IFN/RBV in CH-C patients.

Methods: Clinical data and gene expression data were available for 56 patients treated with PEG-IFN/RBV. Whole blood was used to determine IL28B genotypes. Differential expression of 153 human genes was assessed for each treatment time point (Days: $0,1,7,28,56$ ) and was correlated with IL28B genotype (IL28B C/C or non-C/C) over the course of the PEG-IFN/RBV treatment. Genes with statistically significant changes in their expression at each time point were used as an input for pathway analysis using KEGG Pathway Painter (KPP). Pathways were ranked based on number of gene involved separately per each study cohort.

Results: The most striking difference between the response patterns of patients with IL28B C/C and T* genotypes during treatment, across all pathways, is a sustained pattern of treatment-induced gene expression in patients carrying IL28B C/C. In the case of IL28B T* genotype, pre-activation of genes, the lack of sustained pattern of gene expression or a combination of both were observed. This observation could potentially provide an explanation for the lower rate of SVR observed in these patients. Additionally, when the lists of IL28B genotype-specific genes which were differentially expressed in patients without SVR were compared th their baseline, IRF2 and SOCS1 genes were down-regulated regardless of patients' IL28B genotype. Furthermore, our data suggest that $\mathrm{CH}-\mathrm{C}$ patients who do not have the SOCS1 gene silenced have a better chance of achieving SVR. Our observations suggest that the action of SOCS1 is independent of IL28B genotype.
\end{abstract}

Conclusions: IL28B CC genotype patients with $\mathrm{CH}-\mathrm{C}$ show a sustained treatment-induced gene expression profile which is not seen in non-CC genotype patients. Silencing of SOCS1 is a negative and independent predictor of SVR. These data may provide some mechanistic explanation for higher rate of SVR in IL28B CC patients who are treated with PEG-IFN/RBV.

Keywords: HCV, Gene Expression, Pathway Analysis, IL28B, SOCS1, IRF2, chronic hepatitis C, HCV treatment

\footnotetext{
* Correspondence: zobair.younossi@inova.org

'Betty and Guy Beatty Center for Integrated Research, Inova Health System,

Falls Church, VA, USA

Full list of author information is available at the end of the article
} 


\section{Background}

The most common cause of chronic liver disease, chronic hepatitis $\mathrm{C}$ virus $(\mathrm{CH}-\mathrm{C})$, affects approximately 170 million people worldwide [1]. Until recently, treatment of $\mathrm{CH}-\mathrm{C}$ included a combination of pegylated interferon- $\alpha$ (PEG-IFN- $\alpha$ ) and ribavirin (RBV). This treatment typically led to sustained virologic response (SVR) rates of $47 \%$ to $54 \%$ for previously untreated patients $[2,3]$. Subsequent studies have clarified that the success of this treatment is affected by several host, viral, and treatment factors. Host factors that can influence SVR include obesity, presence of cirrhosis, ethnicity, gender, and age [4-7]. Recently, a landmark genome wide association study of about $1,600 \mathrm{CH}-\mathrm{C}$ patients has identified a single nucleotide polymorphism (SNP) on chromosome 19q13, rs12979860 which was strongly associated with SVR [8]. This SNP is located upstream of the IL28B gene, encoding for IFN- $\lambda 3$. Subsequently, the $\mathrm{C} / \mathrm{C}$ genotype of IL28B was shown to be associated with a greater than 2 fold increase in SVR as compared with the $\mathrm{C} / \mathrm{T}$ and $\mathrm{T} / \mathrm{T}$ genotypes [8]. In addition, a subsequent study provided evidence for strong association of the $\mathrm{C} / \mathrm{C}$ genotype with the spontaneous resolution of $\mathrm{HCV}$ infection [9]. Since these landmark studies, numerous lines of evidence have solidified the association between the IL28B C/C genotype and SVR in patients with $\mathrm{CH}-\mathrm{C}$. Although initially the association of IL28B C/C genotype with spontaneous clearance and SVR were noted in patients with HCV genotype 1 $[10,11]$, more recent data have suggested a similar impact for IL28B on other HCV genotypes [12-15].

Despite the great strides in solidifying the association between IL28B genotypes and SVR, the exact underlying mechanism remains largely unknown [16-18]. In an attempt to shed some light on the potential mechanism of the allelic association of IL28B with SVR, we assessed differential gene expression in $\mathrm{CH}-\mathrm{C}$ patients according to their IL28B genotypes over the course of the PEGIFN/RBV treatment.

\section{Methods}

The study used existing specimen repository for IL28B genotyping as well as our previously reported gene expression and associated clinical data [19]. We selected $\mathrm{CH}-\mathrm{C}$ patients treated with a course of the standard doses of PEG-IFN- $\alpha 2 a$ or PEG-IFN- $\alpha 2 b$ and a weightbased dose of RBV with the duration of treatment based on HCV genotypes $(\mathrm{N}=56)$. Of these 56 patients, 28 were treatment naïve and 28 were previously treated). Clinical, demographic, and laboratory data, as well as blood samples were obtained prior to treatment and during treatment. Blood samples were used for DNA and mRNA extraction as described below.
During treatment, early virologic response (EVR, as defined by $>2 \log$ drop by week 12) and complete virologic response (complete EVR, as defined by undetectable virus by week 12) as well as post treatment sustained virologic response (SVR) rates were determined for each patient.

\section{Ethical approval}

This study is in compliance with the Helsinki Declaration and was approved by the Inova Health Systems Institutional Review Board. Written informed consent was obtained from the participants of this study.

\section{DNA Extraction and Genotyping}

Frozen whole blood was used for IL28B genotyping after genomic DNA extraction using QIAamp DNA Blood Mini kit (Qiagen). IL28B genotyping was performed by tetraprimer refractory mutation system PCR as described by Galmozzi et al [20]. The primers sequences were as follows: outer Fw: 5' AACTCAACGCCTCTTCCTCCT 3'; outer Rv: 5' TTCCCATACACCCGTTCCTGT 3'; inner Fw (T): 5' AGGAGCTCCCCGAAGGAGT 3'; inner Rv (G): 5' GTGCCATTCAACCCTGGTACG 3'. For each sample, we used 20-60 ng of genomic DNA for PCR (HotStarTaq Master Mix Kit; Qiagen) in test tubes containing $20 \mathrm{pmol}$ of each of the four primers to amplify both the "C" and " $T$ " alleles. Genotypes were discriminated by size via standard electrophoresis.

\section{RNA Extraction and Gene Expression Profiling}

As previously reported [19], blood samples for each patient were collected into PAXgene ${ }^{\mathrm{TM}}$ RNA blood tubes (PreAnalytiX) prior to treatment (day 0), 1 day (day 1), 1 week (day 7), 4 weeks (day 28), and 8 weeks (day 56) after the first dosing. From the pre-treatment as well as post treatment PBMCs, total RNA was extracted, quantified and used for one step RT-PCR to profile the expression of 153 human genes that belong to various IFN-inducible and immune response related pathways. Amplification was performed with $\mathrm{SYBR}^{\circledR}$ Green using 5 ng of total RNA as a template in 384well format with a duplicate of each $15-\mu l$ reaction using Prism ${ }^{\circledR} 7900$ HT Sequence Detection System (Applied Biosystems). mRNA expression levels were normalized by using six housekeeping genes, a reference RNA and the $\Delta \Delta$ Ct method [21].

\section{Statistical Analysis}

For each time point (day 0, 1, 7, 28 and 56), differentially expressed genes were separated into up and downregulated gene lists according to the IL28B C/C or non$\mathrm{C} / \mathrm{C}(\mathrm{T} / \mathrm{T}$ or $\mathrm{T} / \mathrm{C})$ genotypes. Additionally, for each time point, gene expression data were also correlated with 
SVR. For each cohort, means and variances of gene expression levels for each gene were calculated. Differentially expressed genes were determined using the Mann-Whitney test (p-value $<0.05$ ) for the expression levels of each gene quantified during each of the five visits.

\section{Pathway Specific Analysis and Mapping}

Pathways specific analyses were performed using the KEGG Pathway Painter (KPP), a novel publicly available tool (http://www.cos.gmu.edu/ gmanyam/kegg/ index.html). KPP is capable of performing real-time batch painting of all relevant KEGG pathways according to differentially expressed gene lists provided by the user and placing these genes within molecular pathways previously described in Kyoto Encyclopedia of Genes and Genomes (KEGG). For each time point (day 0-day 56), the pathways encompassing SVR related genes according to IL28B SNP genotype (C/C or $\mathrm{T}^{*}$ ) were sorted in accordance with the pathway relevance scores, defined as the number of genes highlighted by the gene expression study and divided by the total number of genes within a given pathway. All pathways shared between two or more SVR related genes according to IL28B SNP genotype specific comparisons were automatically painted according to the direction of the gene expression change (activation or suppression). Additionally, pathways relevant to $\mathrm{HCV}$ pathogenesis were selected according to the previously published studies [22,23]. In order to generate a time course image of pathway involvement for SVR related genes according to IL28B SNP genotype, pathways with the highest scores were organized according to relevance scores and time course.

\section{Results}

\section{Patient Population}

Fifty-six patients with $\mathrm{CH}-\mathrm{C}$ were included in this study. The baseline characteristics and treatment response to combination therapy are listed in Table 1.

Of the study cohort, 41\% (23/56) had IL28B CC genotype and 59\% (33/56) had non-CC genotype (TC/TT or $\left.\mathrm{T}^{*}\right)$ genotypes. In $\mathrm{CH}-\mathrm{C}$ patients with IL28B C/C genotype, 65\% (15/23) achieved SVR as compared to $24 \%$ (8/ $33)$ in $\mathrm{CH}-\mathrm{C}$ patients with IL28B T* genotype ( $<0.05)$.

Restricting the analysis only to HCV genotype 1 patients (43/65), the association of IL28B genotypes with SVR remained unchanged (SVR: IL28B C/C: 62.5\%, IL28B T*: 22.2\%, $\mathrm{p}<0.05)$.

IL28B T* genotype was more prevalent in African Americans with $\mathrm{CH}-\mathrm{C}(\mathrm{p}<0.05)$ as compared to all other ethnic groups. Cirrhosis and female gender were negatively associated with SVR only in the IL28B C/C cohort ( $\mathrm{p}<0.0085$ and $\mathrm{p}<0.0037$, respectively).

\section{Gene Expression Profiling}

A total of 150 human genes analyzed in individual qRTPCR assays were profiled across five time points (Day 0; Day1; Day7; Day28; Day56) along the PEG-IFN/RVB treatment. The complete list of analyzed genes could be found in the Additional File 1. Gene expression profiles were used to compare IL28B C/C and IL28B T*cohorts across all time points for the duration of treatment. For each of the time points, the genes were separated into up and down regulated groups according to the genotype. Additionally, for each time point, genotype-specific groups of up- and down-regulated genes which were associated with SVR were identified (Table 2). After the parsing of the data, gene lists were entered into KPP for

Table 1 Characteristics of the patients with IL28B C/C and IL28B T* genotypes.

\begin{tabular}{|c|c|c|c|}
\hline Characteristics & IL28B C/C & IL28B T* & All HCV patients \\
\hline Number of Patients & 23 & 33 & 56 \\
\hline Sex-Female & $6(26.1 \%)$ & $15(45.5 \%)$ & $21(37.5 \%)$ \\
\hline Age & $49.9 \pm 4.4$ & $47.5 \pm 6.7$ & $48.52 \pm 5.96$ \\
\hline Race, African American (\#) & $1(4.3 \%)$ & $8(24.2 \%)$ & $9(16.1 \%)$ \\
\hline Cirrhosis & $5(22.7 \%)$ & $8(25.0 \%)$ & $13(24.1 \%)$ \\
\hline Obesity & $13(56.5 \%)$ & $16(48.5 \%)$ & $29(51.8 \%)$ \\
\hline Diabetes mellitus & $1(4.3 \%)$ & $5(15.2 \%)$ & $6(10.7 \%)$ \\
\hline HCV genotype 1 & $16(65.2 \%)$ & $27(81.8 \%)$ & $43(76.8 \%)$ \\
\hline Pretreatment ALT & $96 \pm 59$ & $111 \pm 79$ & $104 \pm 72$ \\
\hline Pretreatment HCV RNA (IU/mL) & $5,596,354 \pm 6,524,048$ & $4,424,606 \pm 5,295,969$ & $4,893,305 \pm 5,788,661$ \\
\hline High Viral Load (> 850,000 IU/mL) & $17(77.3 \%)$ & $25(75.8 \%)$ & $42(76.4 \%)$ \\
\hline No Complete EVR $\left(p<4.27 \mathrm{e}^{-05}\right)$ & $3(13 \%)$ & $22(68.8 \%)$ & $25(45.5 \%)$ \\
\hline No EVR $(p<0.005)$ & $1(4.3 \%)$ & $12(37.5 \%)$ & $13(26.3 \%)$ \\
\hline Sustained Virologic Response $(p<0.0022)$ & $15(65.2 \%)$ & $8(24.2 \%)$ & $23(41.1 \%)$ \\
\hline
\end{tabular}


pathway analysis. These analyses were repeated for $\mathrm{CH}-\mathrm{C}$ patients with HCV genotype 1 only.

\section{Analysis of the Pathways Associated with SVR across Both} IL28B genotypes

The KPP analysis of genes associated with SVR in both IL28B CC and IL28T* cohorts highlighted several pathways that may play an important role in determining patients' response to interferon-based treatment. These pathways were independently identified for all HCV genotypes as well as specifically for HCV genotype 1 sub-cohort.

When IL28B C/C and IL28B $\mathrm{T}^{*}$ genotypes were compared to each other, the variation between genes grouped in "Hepatitis C infection" pathway was the most striking pathway. This pathway was not only preactivated in the IL28B T* patients, but it was also associated with a distinct pattern of activation and suppression as compared to the IL28B C/C genotype (Table 3).

When the lists of genes highlighted in IL28B C/C vs. T* comparisons were cross-referenced with the list of SVRrelated genes that has been previously reported [20], the sustained pattern of treatment-induced gene expression changes during the entire treatment period was observed only in the IL28B CC patients. On the other hand, in the $\mathrm{T}^{*}$ cohorts, the pre-activation of SVR associated genes was observed. More specifically, gene expression changes in the Hepatitis $\mathrm{C}$ Pathway (Figure 1) were detected in patients with IL28B C/C genotype after a week of treatment. Genes associated with this pathway continued to be differentially expressed at 28 days and 56 days after treatment was initiated. Although, in $\mathrm{CH}-\mathrm{C}$ patients with IL28B $\mathrm{T}^{*}$, genes associated with this pathway were already activated prior to treatment (Day 0) as well as early ( 24 hours) after treatment, this pathway became less pronounced after treatment (Figure 1, Table 3).

Additionally, we identified two other pathways that could potentially differentiate IL28B C/C from $\mathrm{T}^{*}$ genotypes in terms of antiviral response. These pathways were the Measles Pathway (Figure 2) and Chemokine Signaling Pathway (Table 4).

\section{Analysis of the Pathways Associated with Treatment- failure Across Both IL28B Genotypes}

The lists of genes differentially expressed in $\mathrm{CH}-\mathrm{C}$ patients who did not achieve SVR despite having IL28B C/C genotype (8/23) was compared to IL28B T* genotype patients $(25 / 33)$ who also did not achieve SVR

Table 2 Genes differentially up- or downregulated in SVR in IL28B CC and IL28T* cohorts over the course of the treatment period $(P<0.05)$.

\begin{tabular}{|c|c|c|c|c|c|c|c|c|c|c|}
\hline \multirow[t]{2}{*}{ Alelle } & \multicolumn{2}{|c|}{ Day 0} & \multicolumn{2}{|c|}{ Day 1} & \multicolumn{2}{|c|}{ Day 7} & \multicolumn{2}{|c|}{ Day 28} & \multicolumn{2}{|c|}{ Day 56} \\
\hline & Up & Down & Up & Down & Up & Down & Up & Down & Up & Down \\
\hline \multirow[t]{2}{*}{ IL28B CC } & & None & & & & & ATP6V0B & & & BST2 \\
\hline & $\begin{array}{c}\text { IL1B } \\
\text { IRF2 } \\
\text { NFKB2 } \\
\text { PRDM1 } \\
\text { SOCS1 }\end{array}$ & & $\begin{array}{c}\text { CCL4 } \\
\text { IFITM1 } \\
\text { SSBP1 }\end{array}$ & $\begin{array}{c}\text { LIPA } \\
\text { PRKRA }\end{array}$ & $\begin{array}{c}\text { ADAR } \\
\text { ATP6V0B } \\
\text { BTG1 } \\
\text { CCL3 } \\
\text { CCL4 } \\
\text { CREB1 } \\
\text { ICAM1 } \\
\text { IKBKG } \\
\text { IRF1 } \\
\text { LYN } \\
\text { PLAUR } \\
\text { PRKRIR } \\
\text { RNASEL } \\
\text { SOCS1 } \\
\text { STAT3 } \\
\text { STAT6 } \\
\text { TAP2 }\end{array}$ & $\begin{array}{l}\text { FYN } \\
\text { IRF3 }\end{array}$ & $\begin{array}{c}\text { EIF2AK2 } \\
\text { FAS } \\
\text { GBP1 } \\
\text { GTPBP2 } \\
\text { IFI35 } \\
\text { IFI44 } \\
\text { IFI44L } \\
\text { IFIT1 } \\
\text { IFIT2 } \\
\text { IFIT5 } \\
\text { IFITM3 } \\
\text { IRF7 } \\
\text { SELL } \\
\text { SP110 } \\
\text { TAP2 } \\
\text { TRIM34 }\end{array}$ & $\begin{array}{c}\text { DHX9 } \\
\text { FYN } \\
\text { IRF3 } \\
\text { LIPA }\end{array}$ & IFITM3 & $\begin{array}{c}\text { CD81 } \\
\text { FYN } \\
\text { IKBKB } \\
\text { IRF3 } \\
\text { MX1 } \\
\text { PSME2 } \\
\text { TRIM14 } \\
\text { TRIM26 } \\
\text { TRIM34 }\end{array}$ \\
\hline IL28B T* & $\begin{array}{c}\text { AIM2 } \\
\text { IKBKE } \\
\text { IRF2 } \\
\text { LCK } \\
\text { SOCS1 }\end{array}$ & STAT6 & $\begin{array}{c}\text { IRF2 } \\
\text { LCK } \\
\text { TRAF6 }\end{array}$ & $\begin{array}{l}\text { NMI } \\
\text { YARS }\end{array}$ & $\begin{array}{c}\text { BTG1 } \\
\text { CREB1 } \\
\text { FAS } \\
\text { GMPR } \\
\text { HIF1A } \\
\text { IFNAR1 } \\
\text { IRF2 } \\
\text { SELL } \\
\text { SOCS1 } \\
\text { TAP1 } \\
\text { TGFB1 } \\
\text { TRADD } \\
\text { TRAF6 }\end{array}$ & $\begin{array}{c}\text { IL10 } \\
\text { SHFM1 } \\
\text { YARS }\end{array}$ & IFNAR1 & $\begin{array}{c}\text { NMI } \\
\text { PRKRA }\end{array}$ & CREB1 & $\begin{array}{c}\text { CTLA4 } \\
\text { IFI30 } \\
\text { IRF5 }\end{array}$ \\
\hline
\end{tabular}


Table 3 Hepatitis C pathway related genes are differentially regulated in IL28B CC and IL28 T* genotypes over the course of the treatment.

\begin{tabular}{lccccc}
\hline Genotype & Day 0 & Day 1 & Day 7 & Day 28 & Day 56 \\
\hline IL28B CC & $(0)$ & $(0)$ & (5) & $(3)$ & $(3)$ \\
& & & RNASEL & IRF3 & CD81 \\
& & & IRF3 & EIF2AK2 (PKR) & IRF3 \\
& & & IKBKG & IFIT1 & IKBKB \\
& & & IRF1 & & \\
& & & STAT3 & & \\
\hline IL28B T* & $(1)$ & $(1)$ & $(3)$ & $(1)$ & $(0)$ \\
& IKBKE & TRAF6 & TRAF6 & IFNAR1 & \\
& & & IFNAR1 & & \\
& & & TRADD & &
\end{tabular}

Upregulated genes are shown in bold; Downregulated genes are shown in regular font.

(Table 2). Remarkably, prior to initiation of treatment, IRF2 and SOCS1 genes were independently down-regulated in both groups of IL28B patients. Although these $\mathrm{CH}-\mathrm{C}$ patients had different IL28 B genotypes, they all shared the common characteristic of not achieving SVR and having pre-treatment down-regulation of the IRF2 and SOCS1 genes. Neither SOCS1, nor IRF2 expression levels were different when IL28B C/C genotype and IL28B T* genotype cohorts were compared. The time course of the changes in SOCS1 and IRF2 expression levels in patients who subsequently achieved or not achieved SVR is shown at Figures 3 and 4, respectively.

\section{Discussion}

Although the recent approval of Direct Antiviral Agents (DAA) for treatment of $\mathrm{CH}-\mathrm{C}$ will change the treatment course of $\mathrm{CH}-\mathrm{C}$ patients, over the past decade, the combination of PEG-INF/RBV has been the standard treatment for $\mathrm{CH}-\mathrm{C}$ with $47 \%$ to $54 \%$ SVR rates [24]. Recently, the discovery of IL28B, as a strong predictor of SVR, has brought a great deal of enthusiasm. Multiple studies have shown that $\mathrm{CH}-\mathrm{C}$ patients carrying the $\mathrm{C} / \mathrm{C}$ genotype have a two-fold greater chance of SVR than patients with the $T^{*}$ genotype $(8,10,11)$. Our results are consistent with these data, showing that SVR rates

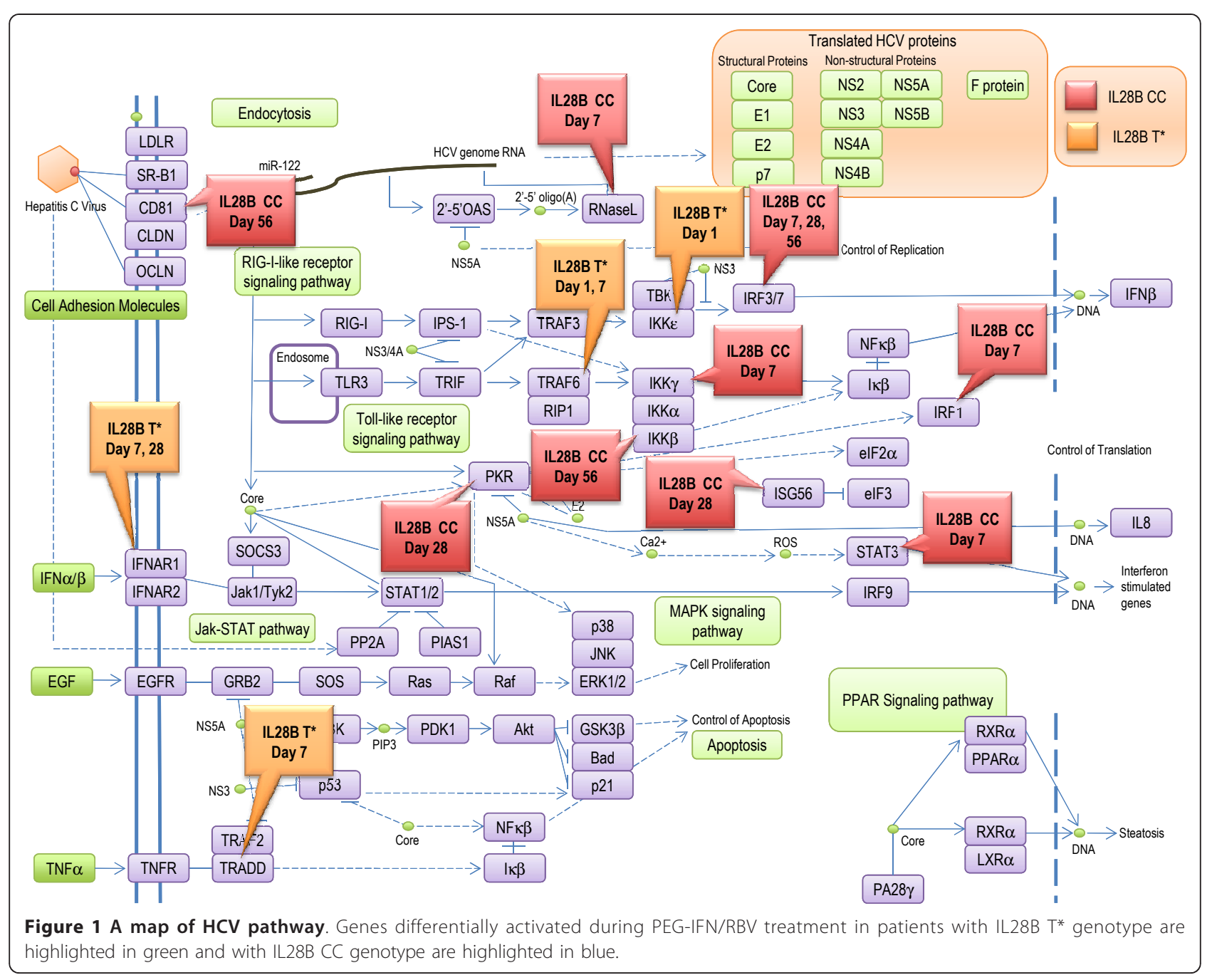




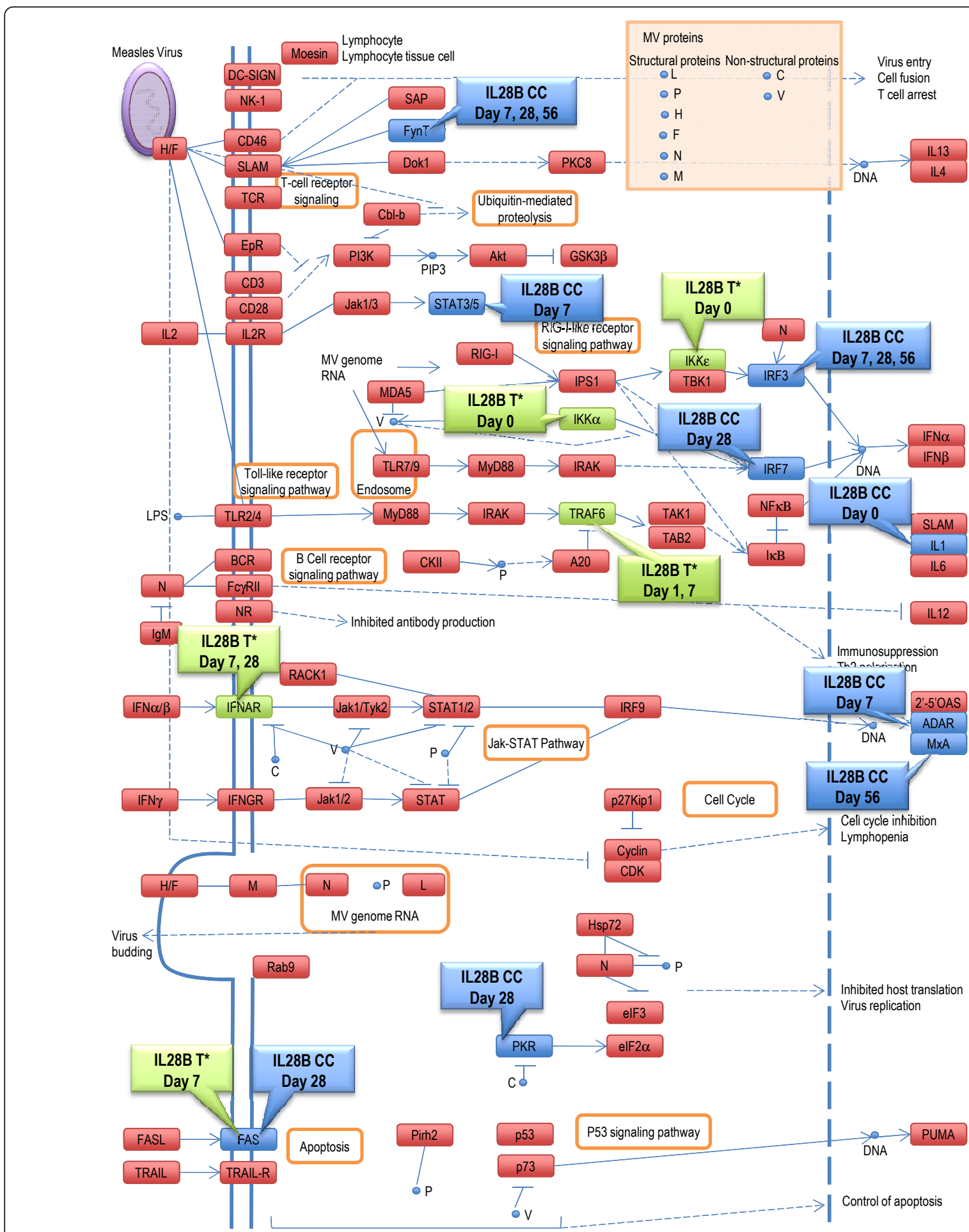

Figure 2 A map of measles pathway. Genes differentially activated during PEG-IFN/RBV treatment in patients with IL28B T* genotype are highlighted in green and with IL28B CC genotype are highlighted in blue.

are 2-3 times higher in $\mathrm{CH}-\mathrm{C}$ patients with IL28B CC genotype.

Additional research has shown that IL28B T* genotype is more common in African American patients with
$\mathrm{CH}-\mathrm{C}[8,9]$ who typically don't respond favorably to PEG-IFN/RBV [25]. Consistent with these data, our study showed a higher prevalence of the $\mathrm{T}^{*}$ allele in African American patients with $\mathrm{CH}-\mathrm{C}$ (Table 1). These 
Table 4 Genes involved in the Cytokine Signaling Pathway related genes are differentially regulated in IL28B CC and IL28 $\mathrm{T}^{*}$ genotypes over the course of the treatment.

\begin{tabular}{lccccc}
\hline Genotype & Day 0 & Day 1 & Day 7 & Day 28 & Day 56 \\
\hline IL28B CC & $(1)$ & $(0)$ & $(4)$ & $(5)$ & $(3)$ \\
& IL1B & & ADAR & EIF2AK2 & FYN \\
& & & FYN & FAS & IRF3 \\
& & & IRF3 & FYN & MX1 \\
& & & STAT3 & IRF3 & \\
& & & & IRF7 & \\
\hline IL28B T* & $(1)$ & $(1)$ & (3) & $(1)$ & $(0)$ \\
& IKBKE & TRAF6 & FAS & IFNAR1 & \\
& & & IFNAR1 & & \\
& & & TRAF6 & &
\end{tabular}

Upregulated genes are shown in bold; Downregulated genes are shown in regular font.

data confirm the role of IL28B genotypes in SVR and provide evidence for validation of our data [26,27].

Despite the strong association between IL28B CC genotype and SVR, the underlying mechanism of IL28 B in determining SVR remains unknown. It is postulated that interferon lambda may produce a better immunologic profile that could favor viral clearance [28]. Recent study by Honda and co-authors demonstrated that the expression of hepatic interferon-stimulated genes is strongly associated with both treatment response and genetic variation of IL28B [29]. In our study, we assessed the impact of PEG-IFN/RBV on the gene expression profiles in PBMCs of patients with $\mathrm{CH}-\mathrm{C}$ during treatment and analyzed these data according to their IL28B genotype status as well as their SVR outcome. We used previously collected gene expression data from a cohort of $\mathrm{CH}-\mathrm{C}$ patients who were undergoing treatment with PEG-IFN/RBV [19] and analyzed

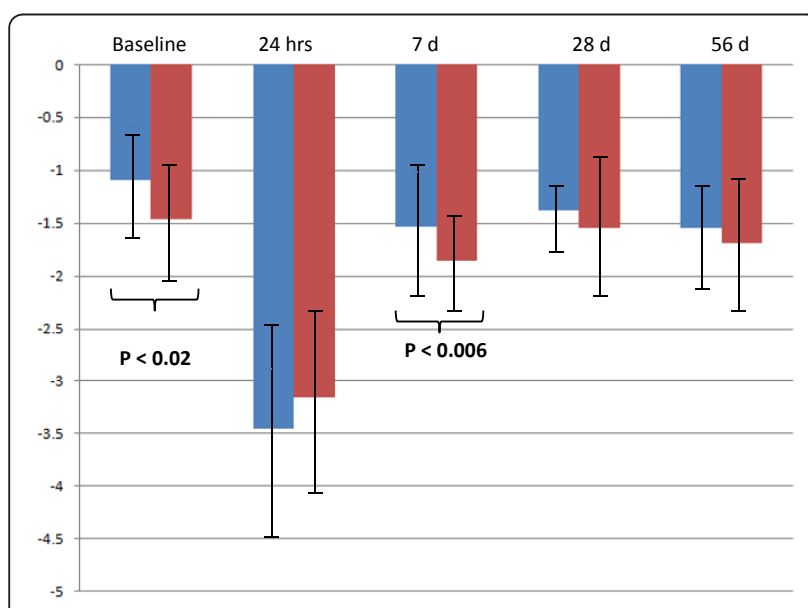

Figure 3 The time course of the changes in SOCS1 expression levels in patients who subsequently achieved or not achieved SVR. Blue columns: patients who achieved SVR $(N=23)$. Red columns: patients who not achieved SVR $(N=33)$

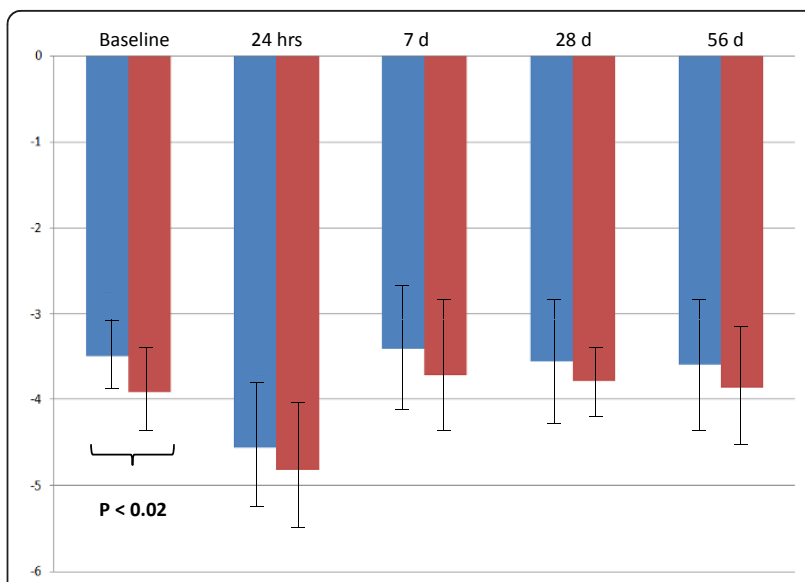

Figure 4 The time course of the changes in IRF2 expression levels in patients who subsequently achieved or not achieved SVR. Blue columns: patients who achieved SVR $(N=23)$. Red columns: patients who not achieved SVR $(N=33)$.

the gene expression profile of these patients according to these patients' IL28B genotype status. Furthermore, this gene expression analysis was coupled with pathway analyses offering a novel approach to the interpretation of gene expression data [26]. This approach provided us with further advancement over previously published time course studies of IFN-inducible genes in PBMCs of HCV patients treated with PEG-IFN/RBV [30,31].

Our approach was validated by the fact that the most commonly activated pathway in our analysis was the Hepatitis C Pathway itself [Figure 1] Analysis of this pathway revealed two interesting observations. First, $\mathrm{CH}-\mathrm{C}$ patients with IL28B $\mathrm{T}^{*}$ genotype seem to have baseline activation of the Hepatitis C Pathway, via the increased expression of the IKBKE gene known to be essential for regulating antiviral signaling, whereas the $\mathrm{CH}-\mathrm{C}$ patients with the IL28B C/C genotype showed activation in this pathway only after the initiation of treatment (Day 7). Second, we observed that IL28B C/C genotype patients with $\mathrm{CH}-\mathrm{C}$ maintained a sustained involvement of this pathway throughout the entire 56 days of treatment with PEG-IFN/RBV; The IL28B T* patients, on the other hand, showed activation at baseline, with minimal involvement past day 7 after the initiation of treatment (Table 3).

Our study also highlighted the Chemokine Signaling as a pathway of interest. In fact, patients with CH-C IL28B $\mathrm{CC}$ genotype showed a clear treatment induced involvement of this pathway, whereas IL28B T* genotype failed to show any treatment induced activation of this pathway (Table 4).

It should be noted that IL28B polymorphisms has not been as strongly associated with treatment outcomes for patients with chronic hepatitis B or human 
immunodeficiency virus to date $[32,33]$. However, it is possible that $\mathrm{HCV}$ shares its regulatory pathways with other types of viruses. In this context, our observation that the pathway related to measles infection is especially intriguing [Figure 2]. In fact, it has been recently shown that the $\mathrm{V}$ protein of the measles virus is a potent inhibitor of IFN-lambda which is encoded by the IL28B gene [34]. It may be interesting to assess any potential association of IL28B and SVR in CH-C patients according to their previous exposure to measles virus or MMR vaccine.

To gain additional insights into the mechanisms of genotype-specific treatment-failure, we compared the lists of genes which were differentially expressed in patients who could not achieve SVR, irrespective of their Il28B genotype status. Remarkably, when gene expression patterns were compared at baseline, IRF2 and SOCS1 genes were independently identified as being down-regulated in all $\mathrm{CH}-\mathrm{C}$ patients who failed treatment, regardless of their IL28B genotypes. Interestingly, transcriptional silencing of the SOCS1 gene in the liver has been suggested as a potential reason for treatment failure in $\mathrm{CH}-\mathrm{C}$ patients as well as in the mouse model of chronic HCV infection [35]. In both instances, silencing of SOCS1 led to permanent activation of the JAK-STAT signaling pathway [35]. Additionally, hepatocytes lacking SOCS-1 exhibit a prolonged response to IFN $\gamma$ [36]. Conversely, when SOCS1 was over-expressed, the propagation of the signal through hepatic interferon-dependent pathways is abrogated [36,37]. In fact, this interferon pathway shutdown also influences IFN $-\lambda$ [37]. Our data collected using PBMCs indicate that the action of SOCS1 is independent of IL28B genotype. Furthermore, our data suggest that $\mathrm{CH}-\mathrm{C}$ patients who do not have the SOCS1 gene silenced have a better chance of achieving SVR. This hypothesis is supported by our previous observation that the lack of SOCS1 suppression in PBMCs could serve as a predictor of SVR, independent of the viral genotype or treatment status [38].

This study has two major limitations, an enrollment of patients infected by different $\mathrm{HCV}$ genotypes and of different ethnicity and evaluation of peripheral blood samples instead of hepatic tissue. However, it is important to note that we carried out our gene expression pathway analyses with all HCV genotypes and then analyzed the data separately for $\mathrm{HCV}$ genotype 1 patients. This was done to assess the impact of HCV genotype- specific response according to IL28B alleles. Nevertheless, the results of our pathway analyses for both HCV genotype groups were very similar, confirming that IL28B acts independent of $\mathrm{HCV}$ genotype.

\section{Conclusions}

In conclusion, the most striking difference between the response patterns of IL28B C/C and T* genotypes to antiviral treatment across all pathways, was the sustained pattern of treatment-induced gene expression in IL28B C/C patients. In the case of IL28 $\mathrm{T}^{*}$ genotype, the pre-activation of this pathway, the lack of sustained activation post treatment or a combination of both, could provide an explanation for their high rate of treatment failure. Further studies are needed to clarify the mechanism of IL28B genotyping and its impact on treatment response.

\section{Additional material}

Additional file 1: The complete list of analyzed genes. This file lists all genes analyzed using qRT-PCR and includes gene names, gene IDs and the biological functions of these genes.

\section{Author details}

${ }^{1}$ Betty and Guy Beatty Center for Integrated Research, Inova Health System, Falls Church, VA, USA. ${ }^{2}$ Center for the Study of Genomics in Liver Diseases, School of Systems Biology, College of Science, George Mason University, Fairfax, VA, USA. ${ }^{3}$ Center for Liver Diseases and Department of Medicine, Inova Fairfax Hospital, Falls Church, VA, USA.

\section{Authors' contributions}

ABar and ZY designed the study and edited the manuscript. AA collected the samples. ME performed genotyping. MS performed statistical analysis. ABar generated SOCS1 graphs. ABir performed KPP analysis and drafted a manuscript. All authors read and approved the final manuscript.

\section{Authors' information}

ABar is an Associate Professor at the School of Systems Biology, College of Science, George Mason University (SSB COS GMU). ABir is Research Assistant Professor at SSB COS GMU. ME and AA are Research Associates at Betty and Guy Beatty Center for Integrated Research, Inova Health System. ZY is a Chairman, Department of Medicine, Inova Fairfax Hospital and Vice President for Research, Inova Health System

\section{Competing interests}

The authors declare that they have no competing interests.

Received: 7 November 2011 Accepted: 7 February 2012 Published: 7 February 2012

\section{References}

1. Alter MJ: Epidemiology of hepatitis C virus infection. World J Gastroenterol 2007, 13:2436-2441.

2. Manns MP, McHutchison JG, Gordon SC, Rustgi VK, Shiffman M, Reindollar R, Goodman ZD, Koury K, Ling M, Albrecht JK: Peginterferon alfa- $2 b$ plus ribavirin compared with interferon alfa- $2 b$ plus ribavirin for initial treatment of chronic hepatitis C: a randomised trial. Lancet 2001, 358:958-965

3. Fried MW, Shiffman ML, Reddy KR, Smith C, Marinos G, Goncales FL Jr, Häussinger D, Diago M, Carosi G, Dhumeaux D, Craxi A, Lin A, Hoffman J, Yu J: Peginterferon alfa-2a plus ribavirin for chronic hepatitis $C$ virus infection. N Engl J Med 2002, 347:975-978.

4. Neumann-Haefelin C, Spangenberg HC, Blum HE, Thimme R: Host and viral factors contributing to CD8+ T cell failure in hepatitis $C$ virus infection. World J Gastroenterol 2007, 13:4839-4847. 
5. Chen TY, Hsieh YS, Wu TT, Yang SF, Wu CJ, Tsay GJ, Chiou HL: Impact of serum levels and gene polymorphism of cytokines on chronic hepatitis C infection. Transl Res 2007, 150:116-121.

6. Younossi Z, McCullough A: Metabolic Syndrome, Non-Alcoholic Fatty Liver Disease and Hepatitis C Virus: Impact on Disease Progression and Treatment Response. Liver Int 2009, 29(Suppl. 2):3-12.

7. Sharma P, Marrero JA, Fontana RJ, Greenson JK, Conjeevaram H, Su GL, Askari F, Sullivan P, Lok AS: Sustained virologic response to therapy of recurrent hepatitis $C$ after liver transplantation is related to early virologic response and dose adherence. Liver Transp/ 2007, 13:1100-1108.

8. Ge D, Fellay J, Thompson AJ, Simon JS, Shianna KV, Urban TJ, Heinzen EL, Qiu P, Bertelsen AH, Muir AJ, Sulkowski M, McHutchison JG, Goldstein DB: Genetic variation in IL28B predicts hepatitis C treatment-induced viral clearance. Nature 2009, 461(7262):399-401.

9. Thomas DL, Thio CL, Martin MP, Qi Y, Ge D, O'Huigin C, Kidd J, Kidd K, Khakoo SI, Alexander G, Goedert JJ, Kirk GD, Donfield SM, Rosen HR, Tobler LH, Busch MP, McHutchison JG, Goldstein DB, Carrington M: Genetic variation in IL28B and spontaneous clearance of hepatitis C virus. Nature 2009, 461(7265):798-801.

10. Thompson AJ, Muir AJ, Sulkowski MS, Ge D, Fellay J, Shianna KV, Urban T, Afdhal NH, Jacobson IM, Esteban R, Poordad F, Lawitz EJ, McCone J, Shiffman ML, Galler GW, Lee WM, Reindollar R, King JW, Kwo PY, Ghalib RH, Freilich B, Nyberg LM, Zeuzem S, Poynard T, Vock DM, Pieper KS, Patel K, Tillmann HL, Noviello S, Koury K, Pedicone LD, Brass CA, Albrecht JK, Goldstein DB, McHutchison JG: Interleukin-28B polymorphism improves viral kinetics and is the strongest pretreatment predictor of sustained virologic response in genotype 1 hepatitis C virus. Gastroenterology 2010, 139(1):120-9, e18.

11. Suppiah V, Moldovan M, Ahlenstiel G, Berg T, Weltman M, Abate ML, Bassendine M, Spengler U, Dore GJ, Powell E, Riordan S, Sheridan D, Smedile A, Fragomeli V, Müller T, Bahlo M, Stewart GJ, Booth DR, George J: IL28B is associated with response to chronic hepatitis C interferon-alpha and ribavirin therapy. Nat Genet 2009, 41(10):1100-4.

12. Mangia A, Thompson AJ, Santoro R, Piazzolla V, Tillmann HL, Patel K, Shianna KV, Mottola L, Petruzzellis D, Bacca D, Carretta V, Minerva N, Goldstein DB, McHutchison JG: An IL28B polymorphism determines treatment response of hepatitis $C$ virus genotype 2 or 3 patients who do not achieve a rapid virologic response. Gastroenterology 2010, 139(3):821-7, 827.e1.

13. Indolfi G, Sambrotta M, Moriondo M, Azzari C, Resti M: Genetic variation in IL28B locus is associated with spontaneous clearance of HCV in children with Non-1 viral genotype infection. Hepatology 2011

14. Lindh $M$, Lagging $M$, Färkkilä $M$, Langeland $N$, Mørch K, Nilsson S, Norkrans G, Pedersen C, Buhl MR, Westin J, Hellstrand K: Interleukin 28B Gene Variation at rs 12979860 Determines Early Viral Kinetics During Treatment in Patients Carrying Genotypes 2 or 3 of Hepatitis C Virus. J Infect Dis 2011, 203(12):1748-52.

15. Yu ML, Huang CF, Huang JF, Chang NC, Yang JF, Lin ZY, Chen SC, Hsieh MY, Wang LY, Chang WY, Li YN, WU MS, Dai CY, Juo SH, Chuang WL: Role of interleukin-28B polymorphisms in the treatment of hepatitis $\mathrm{C}$ virus genotype 2 infection in Asian patients. Hepatology 2011, 53(1):7-13.

16. Rauch A, Kutalik Z, Descombes P, Cai T, Di lulio J, Mueller T, Bochud M, Battegay M, Bernasconi E, Borovicka J, Colombo S, Cerny A, Dufour JF, Furrer H, Günthard HF, Heim M, Hirschel B, Malinverni R, Moradpour D, Müllhaupt B, Witteck A, Beckmann JS, Berg T, Bergmann S, Negro F, Telenti A, Bochud PY, Swiss Hepatitis C Cohort Study; Swiss HIV Cohort Study: Genetic variation in IL28B is associated with chronic hepatitis C and treatment failure: a genome-wide association study. Gastroenterology 2010, 138(4):1338-45, 1345.e1-7.

17. Tillmann HL, Thompson AJ, Patel K, Wiese M, Tenckhoff H, Nischalke HD, Lokhnygina Y, Kullig U, Göbel U, Capka E, Wiegand J, Schiefke I, Güthoff W, Grüngreiff K, König I, Spengler U, McCarthy J, Shianna KV, Goldstein DB, McHutchison JG, Timm J, Nattermann J, German Anti-D Study Group: A polymorphism near IL28B is associated with spontaneous clearance of acute hepatitis C virus and jaundice. Gastroenterology 2010, 139(5):1586-92, 1592.e1.

18. Grebely J, Petoumenos K, Hellard M, Matthews GV, Suppiah V, Applegate T, Yeung B, Marks P, Rawlinson W, Lloyd AR, Booth D, Kaldor JM, George J, Dore GJ, ATAHC Study Group: Potential role for interleukin-28B genotype in treatment decision-making in recent hepatitis $\mathrm{C}$ virus infection. Hepatology 2010, 52(4):1216-24.
19. Younossi ZM, Baranova A, Afendy A, Collantes R, Stepanova M, Manyam G, Bakshi A, Sigua CL, Chan JP, Iverson AA, Santini CD, Chang SY: Early gene expression profiles of patients with chronic hepatitis $C$ treated with pegylated interferon-alfa and ribavirin. Hepatology 2009, 49(3):763-74.

20. Galmozzi E, Menico BD, Rametta R, Dongiovanni P, Fracanzani AL, Benedan L, Borroni V, Maggioni P, Fargion S, Valenti L: A tetra-primer amplification refractory mutation system polymerase chain reaction for the evaluation of rs12979860 IL28B genotype. J Viral Hepat 2010.

21. Livak KJ, Schmittgen TD: Analysis of relative gene expression data using real-time quantitative PCR and the 2(-Delta Delta C(T)) Method. Methods 2001, 25:402-8.

22. Tang H, Grisé H: Cellular and molecular biology of HCV infection and hepatitis. Clin Sci 2009, 117:49-65.

23. Roe B, Hall WW: Cellular and molecular interactions in coinfection with hepatitis $C$ virus and human immunodeficiency virus. Expert Rev Mol Med 2008, 10:e30.

24. Hayashi N, Takehara T: Antiviral therapy for chronic hepatitis C: past, present, and future. J Gastroenterol 2006, 41(1):17-27.

25. Muir AJ, Hu KQ, Gordon SC, Koury K, Boparai N, Noviello S, Albrecht JK, Sulkowski MS, McCone J: Hepatitis C treatment among racial and ethnic groups in the IDEAL trial. J Viral Hepat 2011, 18(4):e134-43.

26. Birerdinc A, Afendy A, Stepanova M, Younossi I, Manyam G, Baranova A, Younossi ZM: Functional pathway analysis of genes associated with response to treatment for chronic hepatitis C. J Viral Hepat 2010, 17(10):730-6.

27. Satapathy SK, Lingisetty CS, Proper S, Chaudhari S, Williams S: Equally poor outcomes to pegylated interferon-based therapy in African Americans and Hispanics with chronic hepatitis C infection. J Clin Gastroenterol 2010, 44(2):140-5.

28. Urban TJ, Thompson AJ, Bradrick SS, Fellay J, Schuppan D, Cronin KD, Hong L, McKenzie A, Patel K, Shianna KV, McHutchison JG, Goldstein DB, Afdhal N: IL28B genotype is associated with differential expression of intrahepatic interferon-stimulated genes in patients with chronic hepatitis C. Hepatology 2010, 52(6):1888-96.

29. Honda M, Sakai A, Yamashita T, Nakamoto Y, Mizukoshi E, Sakai Y, Yamashita T, Nakamura M, Shirasaki T, Horimoto K, Tanaka Y, Tokunaga K, Mizokami M, Kaneko S, Hokuriku Liver Study Group: Hepatic ISG expression is associated with geneticvariation in interleukin $28 \mathrm{~B}$ and the outcome of IFN therapy for chronic hepatitis C. Gastroenterology 2010, 139(2):499-509.

30. Huang C, Chen H, Cassidy W, Howell CD: Peripheral blood gene expression profile associated with sustained virologic response after peginterferon plus ribavirin therapy for chronic hepatitis-C genotype 1. $\rfloor$ Natl Med Assoc 2008, 100(12):1425-33.

31. Xing $T J, X v$ HT, Zhao W, Shen L, Li H, Cai RT: Application of interferon response-related gene array to the antiviral treatment outcome in chronic hepatitis C. Hepatogastroenterology 2010, 57(102-103):1257-63.

32. Martin MP, Qi Y, Goedert JJ, Hussain SK, Kirk GD, Hoots WK, Buchbinder S, Carrington M, Thio CL: IL28B polymorphism does not determine outcomes of hepatitis B virus or HIV infection. J Infect Dis 2010, 202(11):1749-53.

33. Rallon NI, Restrepo C, Naggie S, Lopez M, Del Romero J, Goldstein D, McHutchison J, Soriano V, Benito JM: Interleukin-28B gene polymorphisms do not influence the susceptibility to HIV-infection or CD4 cell decline. AIDS 2011, 25(2):269-71.

34. Caignard G, Bouraï M, Jacob Y, Infection-MAPping project I-MAP, Tangy F, Vidalain PO: Inhibition of IFN-alpha/beta signaling by two discrete peptides within measles virus $\vee$ protein that specifically bind STAT1 and STAT2. Virology 2009, 383(1):112-20.

35. Miyoshi H, Fujie H, Shintani Y, Tsutsumi T, Shinzawa S, Makuuchi M, Kokudo N, Matsuura Y, Suzuki T, Miyamura T, Moriya K, Koike K: Hepatitis C virus core protein exerts an inhibitory effect on suppressor of cytokine signaling (SOCS)-1 gene expression. J Hepatol 2005, 43(5):757-63.

36. Brysha M, Zhang JG, Bertolino P, Corbin JE, Alexander WS, Nicola NA, Hilton DJ, Starr R: Suppressor of cytokine signaling-1 attenuates the duration of interferon gamma signal transduction in vitro and in vivo. $J$ Biol Chem 2001, 276(25):22086-9.

37. Brand S, Zitzmann K, Dambacher J, Beigel F, Olszak T, Vlotides G, Eichhorst ST, Göke B, Diepolder H, Auernhammer CJ: SOCS-1 inhibits expression of the antiviral proteins $2^{\prime}, 5^{\prime}-\mathrm{OAS}$ and MxA induced by the 
novel interferon-lambdas IL-28A and IL-29. Biochem Biophys Res Commun 2005, 331(2):543-8.

38. Younossi ZM, Afendy A, Stepanova M, Hossain N, Younossi I, Ankrah K, Gramlich T, Baranova A: Gene expression profile associated with superimposed non-alcoholic fatty liver disease and hepatic fibrosis in patients with chronic hepatitis C. Liver Int 2009, 29(9):1403-12.

doi:10.1186/1479-5876-10-25

Cite this article as: Younossi et al:: The impact of IL28B genotype on the gene expression profile of patients with chronic hepatitis $C$ treated with pegylated interferon alpha and ribavirin. Journal of Translational Medicine 2012 10:25

Submit your next manuscript to BioMed Central and take full advantage of:

- Convenient online submission

- Thorough peer review

- No space constraints or color figure charges

- Immediate publication on acceptance

- Inclusion in PubMed, CAS, Scopus and Google Scholar

- Research which is freely available for redistribution

Submit your manuscript at www.biomedcentral.com/submit 